\title{
Endovascular treatment of an aorto-oesophageal fistula caused by oesophageal cancer
}

\author{
Tulio Leite, ${ }^{1}$ Lucas Alves Sarmento Pires, ${ }^{2,3}$ Carlos Alberto Araujo Chagas ${ }^{3}$
}

${ }^{1}$ Interventional Radiology Unit, Radiology Institute, Medical School, University of São Paulo, São Paulo, Brazil, Uberlandia, Brazil

${ }^{2}$ Department of Morphology, Universidade Federal Fluminense Faculdade de Medicina, Niteroi, Brazil

${ }^{3}$ Morphology Department, Universidade Federal

Fluminense, Niteroi, Brazil

\section{Correspondence to}

Dr Tulio Leite,

tuliofabiano@hotmail.com

Accepted 12 July 2018

\section{DESCRIPTION}

Aorto-oesophageal fistula (AOF) is commonly the product of aortic aneurysms or iatrogenic injuries during endovascular aortic procedures; despite that, $\mathrm{AOF}$ is an uncommon medical condition. In rare cases, it can be the product of an oesophageal carcinoma. It is a fatal condition, and its treatment options are scarce due to its low incidence. ${ }^{12}$ The case presented herein aims to show an endovascular treatment for AOF.

A 50-year-old male patient presented with odynophagia, progressive dysphagia and weight loss for 4 months prior to the consultation. The patient sought the emergency healthcare service due to haematemesis and melena for 6 days. He was submitted to haemodynamic recovery, blood transfusion and to an upper gastrointestinal tract endoscopy, which revealed an ulcerative and vegetative tumouration on his oesophagus $25 \mathrm{~cm}$ below his upper dental arcade. Biopsy confirmed the hypothesis of a malignant oesophageal carcinoma with moderate cell differentiation. Despite the aforementioned interventions, his blood cell count decreased, and his haematemesis worsened; thus, immediate radiotherapy was performed (400 cGY) to treat the tumour.

On the next day, the patient still presented with haematemesis and a low blood cell count.

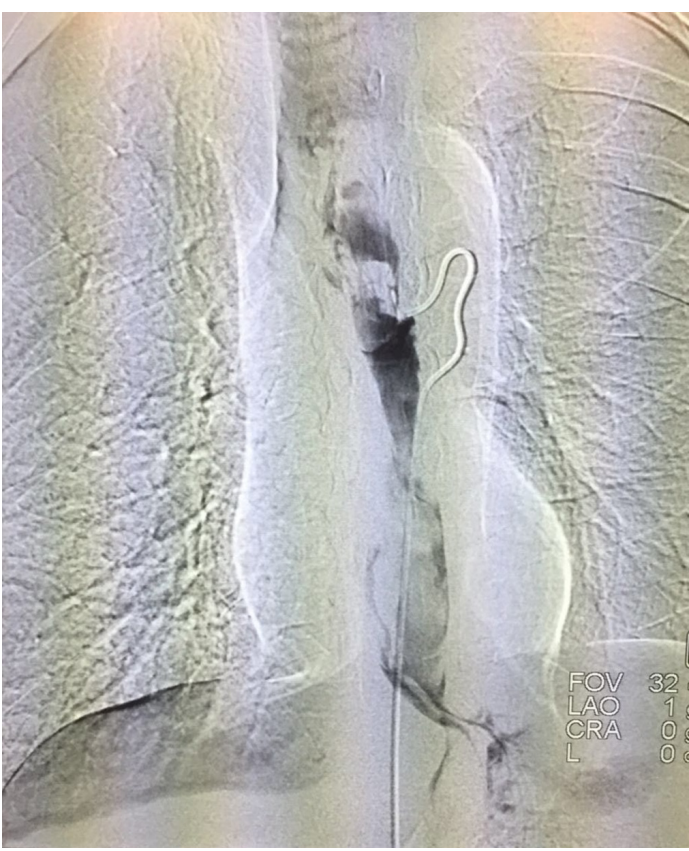

Figure 1 Arteriography showing opacification of the oesophagus characterising an aorto-oesophageal fistula.

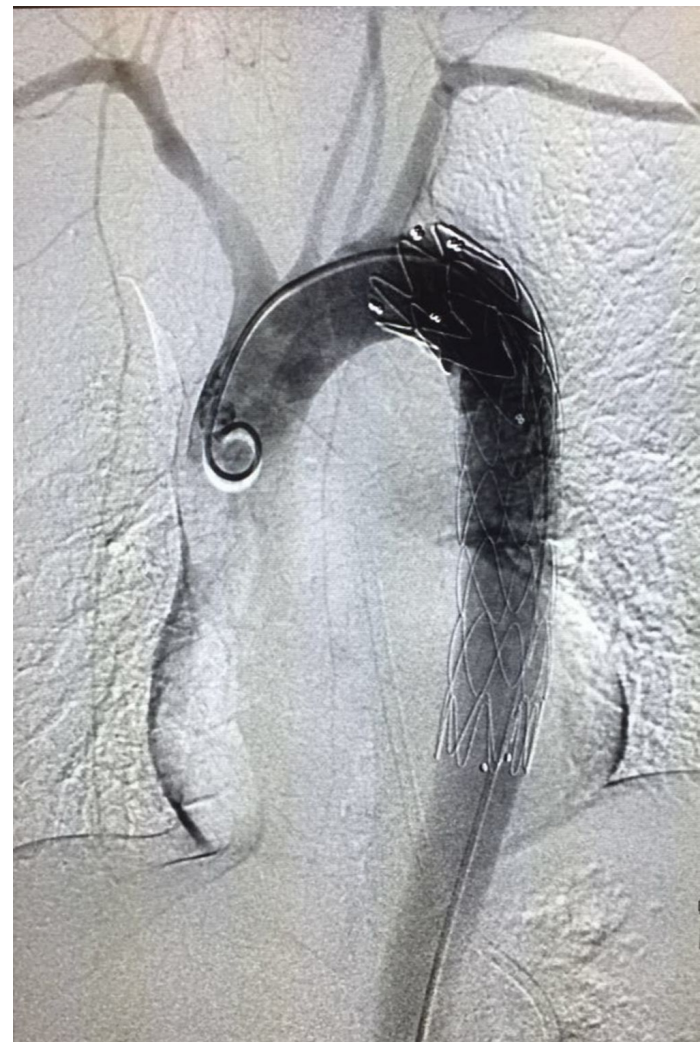

Figure 2 Postoperatory arteriography displaying the endovascular prosthesis and resolution of the aortooesophageal fistula.

Embolisation of the gastro-oesophageal arteries was performed. An aortic arteriography was performed, although no active haemorrhage was found. However, when the oesophageal branches were identified, an AOF was encountered (figure 1). Vasa vasorum bleeding was ruled out due to massive blood loss and subsequent haemodynamic complications.

A $32 \times 32 \times 150 \mathrm{~mm}$ endoprosthesis (Valiant Captivia, Medtronik, Minnesota, USA) was placed on origin of the left subclavian artery, and a $46 \mathrm{~mm}$ accommodation balloon (Reliant, Medtronik) was placed on the aorta (figure 2). Open thoracic surgery was not performed, as it possesses higher mortality rates than endovascular treatments.

Follow-up arteriography was performed that showed resolution of the AOF; however, the patient went to the intensive care unit highly unstable. Vasoactive drugs were administered, and blood transfusion was performed as well; however, due to massive blood loss prior to the surgery (hypovolaemic shock), the patient died 24 hours later. 


\section{Learning points}

Despite rare, oesophageal cancer can be a cause of aortooesophageal fistulas.

- Endovascular treatment for these fistulas can be successfully achieved.

Contributors TL was responsible for the surgery, writing the case reports and the family consent. LASP was responsible for writing the article and obtaining the images. CAAC was the guarantor and supervisor of the paper and its content. All authors approved the final version of the manuscript.
Funding The authors have not declared a specific grant for this research from any funding agency in the public, commercial or not-for-profit sectors.

Competing interests None declared.

Patient consent Next of kin consent obtained.

Provenance and peer review Not commissioned; externally peer reviewed.

\section{REFERENCES}

1 Cheng L, Zhu J, Liu X, et al. A successful three-stage surgical treatment for aortoesophageal fistula after thoracic endovascular aortic repair and esophageal stent repair. Ann Thorac Surg 2016;102:e503-5.

2 Uno K, Koike T, Takahashi S, et al. Management of aorto-esophageal fistula secondary after thoracic endovascular aortic repair: a review of literature. Clin I Gastroenterol 2017:10:393-402

Copyright 2018 BMJ Publishing Group. All rights reserved. For permission to reuse any of this content visit http://group.bmj.com/group/rights-licensing/permissions.

BMJ Case Report Fellows may re-use this article for personal use and teaching without any further permission.

Become a Fellow of BMJ Case Reports today and you can:

- Submit as many cases as you like

- Enjoy fast sympathetic peer review and rapid publication of accepted articles

- Access all the published articles

Re-use any of the published material for personal use and teaching without further permission

For information on Institutional Fellowships contact consortiasales@bmjgroup.com

Visit casereports.bmj.com for more articles like this and to become a Fellow 